\title{
ARTIKEL PENELITIAN \\ GAMBARAN AUDIOGRAM NADA MURNI PENDERITA KARSINOMA KEPALA DAN LEHER YANG MENDAPAT SATU SIKLUS KEMOTERAPI CISPLATIN
}

\author{
Sukri Rahman ${ }^{1}$, Widayat Alviandi ${ }^{1}$, Yan Edward ${ }^{2}$, M. Abduh Firdaus ${ }^{2}$, \\ Rizanda Machmud ${ }^{3}$
}

1. Departemen Telinga Hidung Tenggorok Bedah Kepala Leher

Fakultas Kedokteran Universitas Indonesia

2. Bagian Telinga Hidung Tenggorok Bedah Kepala Leher

Fakultas Kedokteran Universitas Andalas

3. Bagian Ilmu Kesehatan Masyarakat Fakultas Kedokteran

Universitas Andalas

E-mail : sukri_rahman@yahoo.com

\begin{abstract}
Abstrak
Sebagian besar keganasan kepala dan leher terdiagnosis sudah dalam stadium lanjut dan sering sudah inoperable. Kemoradiasi merupakan pengobatan pada keadaan seperti ini. Kemoterapi neoadjuvan (induksi) dengan cisplatin pada karsinoma kepala leher telah terbukti dapat mempreservasi organ dan menurunkan angka metastasis jauh, namun di sisi lain cisplatin menyebabkan berbagai efek samping berupa toksik terhadap berbagai organ, salah satunya ototoksik

Penelitian ini bertujuan untuk mengetahui gambaran audiogram nada murni penderita karsinoma kepala dan leher yang mendapat kemoterapi cisplatin.

Penelitian ini merupakan uji potong lintang untuk mengetahui gambaran audiogram nada murni terhadap 25 orang penderita karsinoma kepala dan leher yang mendapat kemoterapi cisplatin $100 \mathrm{mg} / \mathrm{m}^{2}$ di bagian Telinga Hidung Tenggorok Bedah Kepala Leher (THT-KL) rumah sakit (RS) Dr. M. Djamil Padang, mulai bulan April sampai bulan Desember 2009.

Dari 50 audiogram yang diperiksa didapatkan nilai rerata perubahan nilai ambang dengar hantaran tulang pada masing-masing frekuensi yaitu $3,4 \pm 5,84 \mathrm{~dB}$ pada frekuensi $250 \mathrm{~Hz}, 2,0 \pm 3,91 \mathrm{~dB}(500 \mathrm{~Hz}), 2,6 \pm 4,87 \mathrm{~dB}(1000 \mathrm{~Hz}), 3,4 \pm 5,10 \mathrm{~dB}$ $(2000 \mathrm{~Hz}), 4,9 \pm 9,23 \mathrm{~dB}(4000 \mathrm{~Hz}), 4,7 \pm 5,84 \mathrm{~dB}(6000 \mathrm{~Hz})$ dan $6,5 \pm 9,85 \mathrm{~dB}$ pada $8000 \mathrm{~Hz}$.

Setelah pemberian satu siklus kemoterapi cisplatin $100 \mathrm{mg} / \mathrm{m}^{2}$ sebagian besar sampel tidak mengalami perubahan ambang dengar pada frekuensi 250, 500, 1000, 2000, 4000 dan $6000 \mathrm{~Hz}$, sedangkan pada frekuensi $8000 \mathrm{~Hz}$, sebagian besar mengalami kenaikan nilai ambang dengar. Namun demikian nilai rerata hantaran tulang sebelum dengan setelah kemoterapi terdapat perbedaan yang bermakna pada semua frekuensi.
\end{abstract}

Kata kunci : ototoksik, kemoterapi neoadjuvan, cisplatin, audiometri nada murni 


\section{Abstract}

The majority of head and neck malignancy was diagnosed in an advanced stage and often had inoperable. Chemoradiation is a treatment in this state. Neoadjuvan chemotherapy with cisplatin in carcinoma of the head and neck has been able to preserve organs and reduce the number of distant metastases, but on the other hand, cisplatin cause various side effects as toxic to the various organs, such as ototoxicity.

This study aims to find out changes in hearing threshold of pure tone audiometry of head and neck carcinoma patients receiving cisplatin chemotherapy.

This was a cross-sectional study to evaluate pure tone audiogram of 25 head and neck carcinoma patients who received chemotherapy cisplatin $100 \mathrm{mg} / \mathrm{m}^{2}$ at the Department of Otorhinolaryngology Head and Neck surgery Dr. M. Djamil Hospital Padang, from April to December 2009.

Of the 50 examined audiogram obtained the mean value of changes in bone conduction hearing threshold at each frequency of $3.4 \pm 5.84 \mathrm{~dB}$ at $250 \mathrm{~Hz}, 2.0 \pm$ $3.91 \mathrm{~dB}(500 \mathrm{~Hz}) 2.6 \pm 4.87 \mathrm{~dB}(1000 \mathrm{~Hz}), 3.4 \pm 5.10 \mathrm{~dB}(2000 \mathrm{~Hz}), 4.9 \pm 9.23$ $\mathrm{dB}(4000 \mathrm{~Hz}), 4.7 \pm 5.84 \mathrm{~dB}(6000 \mathrm{~Hz})$ and $6,5 \pm 9.85 \mathrm{~dB}$ at $8000 \mathrm{~Hz}$.

After treatment with one course of $100 \mathrm{mg} / \mathrm{m}^{2}$ cisplatin chemotherapy most samples did not change the hearing threshold at frequency of 250, 500, 1000, 2000, 4000 and $6000 \mathrm{~Hz}$, whereas at $8000 \mathrm{~Hz}$, the majority has increased the hearing threshold. However, the average value of bone conduction before and after chemotherapy showed significant difference at all frequencies.

Key words : ototoxicity, neoadjuvant chemotherapy, cisplatin, pure tone audiometry 


\section{Pendahuluan}

Cisplatin [cis-diklorodiamin

platinum (II)] merupakan obat kemoterapi yang sering digunakan dan efektif untuk penatalaksanaan berbagai keganasan, termasuk keganasan di kepala dan leher. ${ }^{(1,2)}$

Sebagian besar $(60 \%)$

keganasan kepala dan leher terdiagnosis sudah dalam stadium lanjut dan sering sudah inoperable. Kemoradiasi merupakan pengobatan pada keadaan seperti ini. Kemoterapi neoadjuvan (induksi) dengan cisplatin dan 5-fluorourasil (5 FU) pada karsinoma kepala leher telah terbukti dapat mempreservasi organ dan secara statistik menurunkan angka metastasis jauh. ${ }^{(3)}$ Disamping efektivitasnya terhadap tumor, di sisi lain cisplatin menyebabkan berbagai efek samping berupa toksik terhadap berbagai organ, salah satunya ototoksik. Ototoksik merupakan efek samping jangka panjang yang sering terabaikan. Pada pemberian cisplatin sering dikombinasi dengan $5 \mathrm{FU}, 5 \mathrm{FU}$ juga dapat menimbulkan berbagai efek samping seperti toksisitas terhadap saluran cerna, mukokutaneus, mielosupresi dan neurotoksik, namun tidak ada laporan bahwa 5 FU bersifat ototoksik. ${ }^{(4,5)}$

Insiden gangguan pendengaran akibat pemberian cisplatin bervariasi dan umumnya cukup tinggi, antara 20 sampai $100 \%{ }^{(6)}$ Berbagai penelitian telah melaporkan usaha untuk pencegahan ototoksisitas yang ditimbulkan cisplatin, namun dihadapkan pada permasalahan, efek proteksi terhadap munculnya ototoksisitas akan mengurangi efek kemoterapi terhadap sel tumor. ${ }^{(6)}$ Deteksi dini dan pemantauan (monitoring) merupakan cara terbaik yang dapat dilakukan karena belum adanya pencegahan yang secara klinis terbukti menurunkan efek ototoksik tanpa mengurangi efek anti neoplastik. ${ }^{(7)}$

Pemeriksaan audiometri nada murni merupakan pemeriksaan yang sederhana dan paling sering digunakan untuk mendeteksi adanya gangguan pendengaran. Beberapa penelitian telah menilai gambaran audiogram penderita yang mendapat terapi cisplatin. Semua laporan konsisten mendapatkan gangguan pendengaran yang terjadi sensori-neural nada/ frekuensi tinggi, sesuai dengan temuan patologis yang terjadi bahwa kerusakan terutama pada bagian basal koklea. ${ }^{(8,9)}$

Peningkatan angka harapan hidup dan kejadian keganasan pada usia muda yang cukup tinggi maka deteksi dini yang efektif dan efesien terhadap terjadinya ototoksik pada pemberian cisplatin merupakan hal yang penting. ${ }^{(10,11)}$

Penelitian ini bertujuan untuk mengetahui gambaran audiogram nada murni penderita karsinoma kepala dan leher yang mendapat kemoterapi cisplatin.

\section{METODE PENELITIAN}

Penelitian ini merupakan uji potong lintang (cross sectional) untuk mengetahui gambaran audiogram nada murni terhadap 25 orang penderita karsinoma kepala dan leher yang mendapat kemoterapi cisplatin di bagian Telinga Hidung Tenggorok Bedah Kepala Leher (THT-KL) rumah sakit (RS) Dr. M. Djamil Padang, mulai bulan April sampai bulan Desember 2009. Semua sampel berusia di atas 17 tahun, tidak pernah mendapat kemoterapi sebelumnya, tidak sedang mendapat obat ototoksik lain serta tidak sedang atau pernah mendapat radioterapi daerah kepala.

Pada semua sampel dilakukan anamnesis, pemeriksaan fisik telinga, 
pemeriksaan otoskopi dan penala. Dilanjutkan dengan pemeriksaan timpanometri dan audiometri nada murni (hantaran tulang dan hantaran udara menggunakan audiometer klinik merk Interacoustic Clinical Audiometer $A C 40$ yang sudah dikalibrasi dan dilakukan dalam ruangan kedap suara, jangkauan frekuensi dari $250-8000$ $\mathrm{Hz}$ dan intensitas dari -10 s.d 110 dB.). Data ini merupakan status pendengaran sebelum mendapat kemoterapi dengan cisplatin.

Selanjutnya penderita akan mendapat kemoterapi pertama sesuai protokol kemo-terapi yang telah rutin dipakai di sub bagian Onkologi THTKL RS. Dr. M. Djamil Padang yaitu kombinasi cisplatin $100 \mathrm{mg} / \mathrm{m}^{2}$ pada hari pertama dan 5-FU 1000 $\mathrm{mg} / \mathrm{m}^{2} /$ hari selama lima hari secara kontinu.

Dua sampai tiga minggu setelah kemoterapi, anamnesis, pemeriksaan telinga, otoskopi dan penala serta audometri nada murni seperti sebelum kemoterapi kembali dilakukan. Data ini merupakan status pendengaran setelah mendapat kemoterapi.

\section{HASIL}

Dari penelitian didapatkan gambaran audiogram dari sampel sangat beragam, ada yang tidak mengalami perubahan ambang dengar, sebagian mengalami perubahan pada frekuensi rendah dan sebagian mengalami perubahan pada frekuensi tinggi. Dari 50 audiogram yang diperiksa dari 25 orang sampel, didapatkan nilai rerata hantaran tulang sebelum dan setelah kemoterapi terlihat pada Gambar 1. Terdapat perbedaan yang bermakna antara nilai rerata hantaran tulang sebelum dengan setelah kemoterapi pada semua frekuensi $(\mathrm{p}<0,05)$.

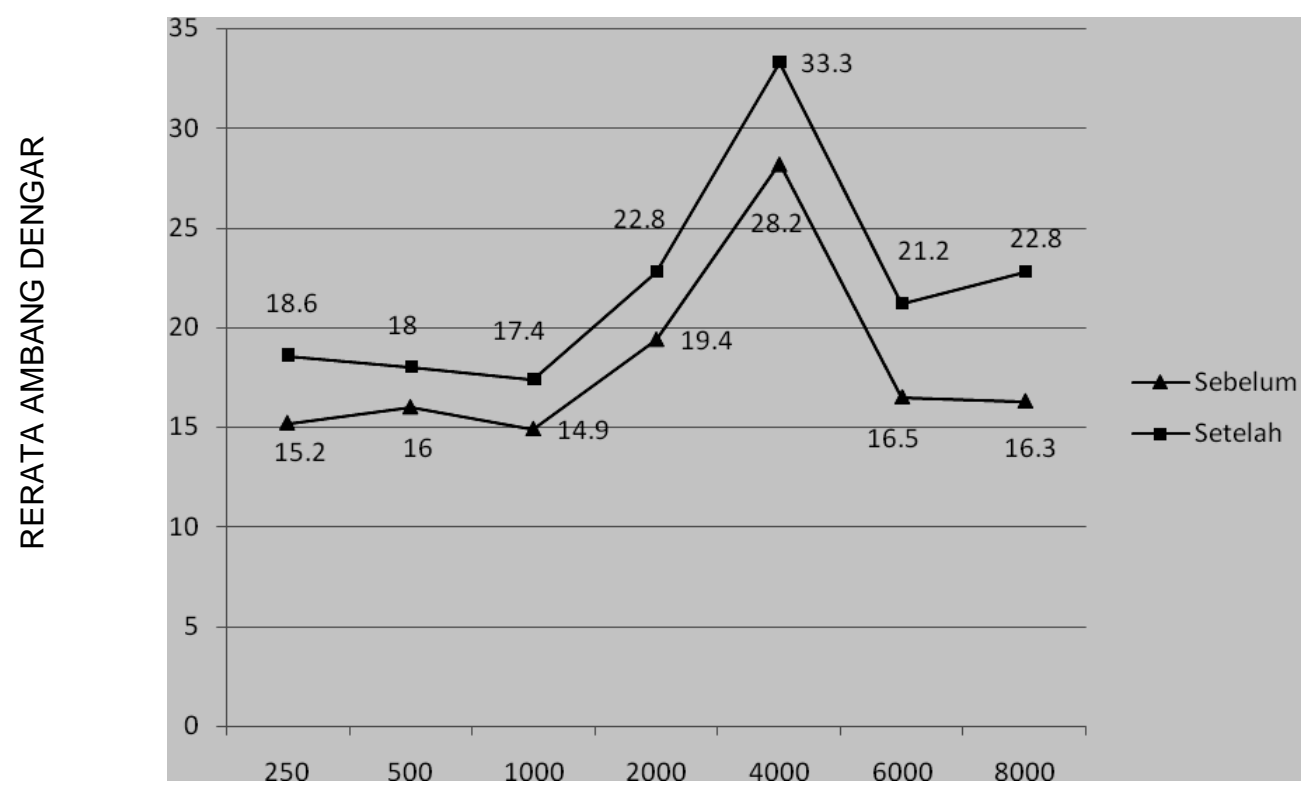

FREKUENSI

Gambar 1. Rerata Ambang Dengar Hantaran Tulang Sebelum dan Setelah Kemoterapi Berdasarkan Frekuensi 


Dari 50 audiogram yang
diperiksa didapatkan nilai rerata
perubahan nilai ambang dengar
hantaran tulang pada masing-masing
frekuensi yaitu $3,4 \pm 5,84 \mathrm{~dB}$ pada
frekuensi $250 \mathrm{~Hz}, 2,0 \pm 3,91 \mathrm{~dB}(500$
$\mathrm{Hz}), 2,6 \pm 4,87 \mathrm{~dB}(1000 \mathrm{~Hz}), 3,4 \pm 5,10$
$\mathrm{~dB}(2000 \mathrm{~Hz}), 4,9 \pm 9,23 \mathrm{~dB}(4000 \mathrm{~Hz})$,
$4,7 \pm 5,84 \mathrm{~dB}(6000 \mathrm{~Hz}) \mathrm{dan} 6,5 \pm 9,85$
dB pada $8000 \mathrm{~Hz}$. (Tabel. 1$).$

Tabel 1. Rerata Perubahan Ambang Dengar Hantaran Tulang Berdasarkan Frekuensi

\begin{tabular}{lll}
\hline \multirow{2}{*}{$\begin{array}{l}\text { Frekuensi } \\
(\mathbf{H z})\end{array}$} & \multicolumn{2}{l}{$\begin{array}{l}\text { Rerata perubahan } \\
\text { ambang dengar }(\mathbf{d B})\end{array}$} \\
\cline { 2 - 3 } & $\mathbf{X}$ & SD \\
\hline 250 & 3,4 & 5,84 \\
500 & 2,0 & 3,91 \\
1000 & 2,6 & 4,87 \\
2000 & 3,4 & 5,09 \\
4000 & 4,9 & 9,23 \\
6000 & 4,7 & 5,84 \\
8000 & 6,5 & 9,85 \\
\hline
\end{tabular}

Ambang dengar hantaran tulang setelah kemoterapi sangat bervariasi antara satu sampel dengan sampel yang lain, ada yang tidak mengalami perubahan namun ada yang mengalami perubahan sampai dengan $45 \mathrm{~dB}$.

Sebagian besar sampel tidak mengalami perubahan ambang dengar pada frekuensi $250 \mathrm{~Hz}$ sampai $6000 \mathrm{~Hz}$ yaitu 33 telinga $(66 \%)$ pada frekuensi $250 \mathrm{~Hz}, 37$ telinga $(74 \%)$ pada $500 \mathrm{~Hz}$, 34 telinga (68\%) pada $1000 \mathrm{~Hz}, 29$ telinga $(58 \%)$ pada $2000 \mathrm{~Hz}, \quad 30$ telinga $(60 \%)$ pada $4000 \mathrm{~Hz}$ dan 26 telinga $(52 \%)$ pada frekuensi $6000 \mathrm{~Hz}$. Sedangkan pada frekuensi $8000 \mathrm{~Hz}$, sebagian besar mengalami kenaikan nilai ambang dengar yaitu 58\% yang terdiri dari $28 \%$ terdapat perubahan kurang dari $10 \mathrm{~dB}$ dan $30 \%$ lebih dari $10 \mathrm{~dB}$. (Gambar 2) 


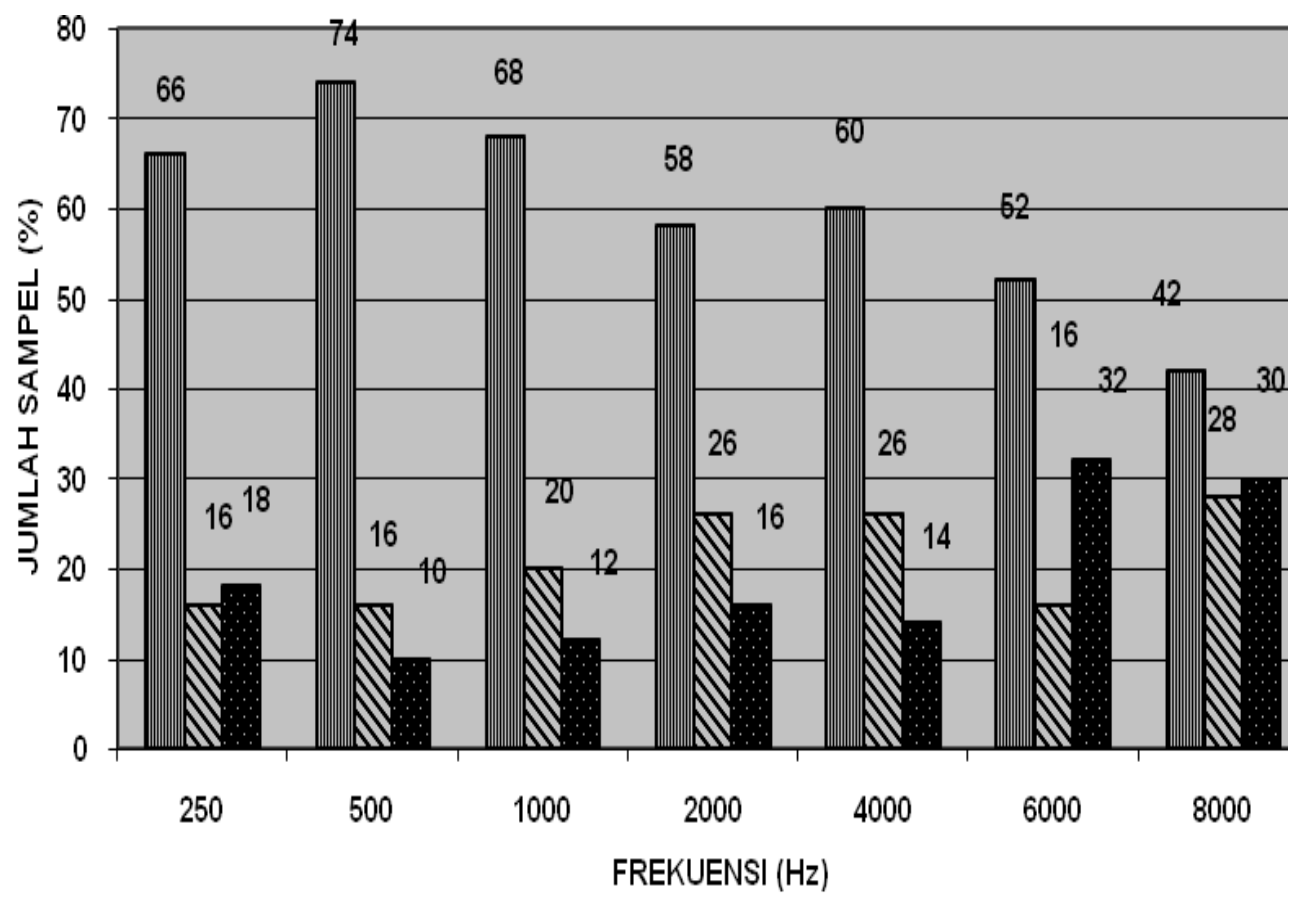

\section{पTidak ada perubahan $\quad$ D1 sampai $<10 \mathrm{~dB} \quad \mathbb{2} \geq 10 \mathrm{~dB}$ \\ Gambar 2. Distribusi Perubahan Ambang Dengar Hantaran Tulang Setelah Kemoterapi Berdasarkan Frekuensi}

Pada tabel 2. terlihat bahwa pada frekuensi tinggi terdapat 9 telinga mengalami kenaikan nilai ambang dengar $\geq 10 \mathrm{~dB}$, sedangkan pada frekuensi rendah hanya 5 telinga yang mengalami kenaikan nilai ambang dengar $\geq 10 \mathrm{~dB}$. Secara statistik perbedaan ini tidak bermakna $(\mathrm{p}>0.05)$.

Tabel 2. Proporsi Perubahan Pendengaran Hantaran Tulang Menurut Kelompok Frekuensi

\begin{tabular}{llllll}
\hline $\begin{array}{l}\text { Fre- } \\
\text { kuensi } \\
(\mathbf{H z})\end{array}$ & $\begin{array}{l}\text { Perubahan } \\
\text { Pendengaran }\end{array}$ & $\begin{array}{l}\text { n } \\
\text { (teli- }\end{array}$ & $\mathbf{2}$ & $\mathbf{p}$ \\
\cline { 2 - 4 } nga) & $\mathbf{1 0} \mathbf{d B}$ & $\begin{array}{l}\mathbf{1 1 0} \\
\mathbf{d B}\end{array}$ & & & \\
\hline Rendah & $\begin{array}{l}45 \\
(90 \%)\end{array}$ & $\begin{array}{l}5 \\
(10 \%)\end{array}$ & 50 & 100 & \\
& 41 & 9 & & & 0,19 \\
Tinggi & $(82 \%)$ & $(18 \%)$ & 50 & 100 & \\
\hline
\end{tabular}

* perbedaan bermakna $(<0,05)$

Frekuensi rendah: rerata ambang dengar pada frekuensi 250, $500,1000,2000 \mathrm{~Hz}$

Frekuensi tinggi: rerata ambang dengar pada frekuensi 4000, 6000, $8000 \mathrm{~Hz}$

\section{PEMBAHASAN}

Nilai rerata ambang dengar hantaran tulang sebelum kemoterapi pada masing-masing frekuensi, yaitu $15,2 \mathrm{~dB}$ pada $250 \mathrm{~Hz}, 16,0 \mathrm{~dB}$ pada $500 \mathrm{~Hz}, 14,9 \mathrm{~dB}$ pada $1000 \mathrm{~Hz}, 19,4$ dB pada $2000 \mathrm{~Hz}, 28,2 \mathrm{~dB}$ pada 4000 $\mathrm{Hz}, 16,5 \mathrm{~dB}$ pada $6000 \mathrm{~Hz}$ dan16,3 dB pada $8000 \mathrm{~Hz}$. Keadaan ini berbeda dengan Schaefer SD $\mathrm{dkk}^{12}$, yang melaporkan nilai rerata ambang 
hantaran tulang sebelum kemoterapi pada frekuensi $4000 \mathrm{~Hz}$ dan $8000 \mathrm{~Hz}$ yang lebih tinggi, berturut-turut $41 \mathrm{~dB}$ dan $46 \mathrm{~dB}$, sedangkan pada frekuensi rendah tidak jauh berbeda. Hal ini dapat terjadi karena pada penelitian yang dilakukan Schaefer SD dkk, sebaran usia sampel lebih tua yaitu antara 51 sampai 69 tahun.

Berbagai penelitian melaporkan hasil yang berbeda tentang hubungan gangguan pendengaran sebelum kemoterapi dengan peningkatan risiko ototoksisitas akibat cisplatin. ${ }^{(11)}$ Laurell $\mathrm{G} \mathrm{dkk},{ }^{(13)}$ melaporkan penderita yang telah mengalami gangguan pendengaran pada frekuensi tinggi sebelum terapi mempunyai risiko yang lebih tinggi untuk mengalami gangguan pendengaran pada frekuensi sedang $(0,5-2 \mathrm{KHz})$ setelah pemberian cisplatin, namun secara umum adanya gangguan pendengaran sebelum terapi tidak meningkatkan risiko ototoksisitas yang terjadi. Durrant JD dkk, ${ }^{(11)}$ juga tidak mendapatkan peningkatan risiko, namun karena telah terjadi gangguan pendengaran sebelumnya, dengan adanya peningkatan ambang dengar setelah terapi akan memperberat gangguan pendengaran yang terjadi, sehingga kecacatan pendengaran pada penderita yang sudah mengalami gangguan pendengaran sebelum terapi akan lebih tinggi.

Hal yang berbeda dilaporkan oleh Zuur CL dkk, ${ }^{(14)}$ yang justru menemukan peningkatan nilai ambang dengar yang lebih besar terjadi pada penderita dengan pendengaran normal sebelum pemberian cisplatin dan radiasi. Pada penelitian ini didapatkan bahwa pada telinga dengan pendengaran normal sebelum kemoterapi, perubahan ambang dengar yang terjadi tidak jauh berbeda dengan rerata perubahan pada semua sampel.
Status pendengaran setelah pembe-rian satu siklus kemoterapi cisplatin $100 \mathrm{mg} / \mathrm{m}^{2}$ menunjukkan audiogram yang beragam. Sebagian besar sampel tidak mengalami perubahan ambang dengar hantaran tulang pada frekuensi rendah (frekuensi 250, 500, 1000 dan $2000 \mathrm{~Hz}$ ) yaitu, $66 \%$ pada frekuensi $250 \mathrm{~Hz}, 74 \%$ pada $500 \mathrm{~Hz}, 68 \%$ pada $1000 \mathrm{~Hz}, 58 \%$ pada $2000 \mathrm{~Hz}$ dan juga pada $4000 \mathrm{~Hz}$ serta $6000 \mathrm{~Hz}$ masing-masing $60 \%$ dan 52\%, sedangkan pada frekuensi $8000 \mathrm{~Hz}$, sebagian besar mengalami kenaikan nilai ambang dengar. Laurell $\mathrm{G} \mathrm{dkk},{ }^{(13)}$ melaporkan $58,8 \% \quad$ penderita mengalami perubahan ambang dengar yang signifikan setelah pemberian dosis tunggal cisplatin $120 \mathrm{mg} / \mathrm{m}^{2}$ dan $23,1 \%$ pada penderita yang mendapat cisplatin $100 \mathrm{mg} / \mathrm{m}^{2}$. Pada sampel yang mengalami peningkatan nilai ambang dengar hantaran tulang, beratnya gangguan pendengaran yang terjadi sangat bervariasi, frekuensi yang terlibat juga bervariasi, namun dari rerata perubahan ambang dengar, kenaikan nilai ambang dengar pada frekuensi $4000 \mathrm{~Hz}, 6000 \mathrm{~Hz}$ dan 8000 $\mathrm{Hz}$ lebih tinggi daripada pada frekuensi rendah $(250 \mathrm{~Hz}, 500 \mathrm{~Hz}, 1000 \mathrm{~Hz}$ dan $2000 \mathrm{~Hz})$.

Bervariasinya perubahan ambang dengar ini juga dilaporkan oleh Schaefer $\mathrm{dkk},{ }^{(12)}$ yang menemukan kenaikan ambang dengar rata-rata pada penderita yang mendapat cisplatin pada frekuensi 250, 500, dan $1000 \mathrm{~Hz}$ hanya $2 \mathrm{~dB}$, pada $2000 \mathrm{~Hz}$ kenaikan $20 \mathrm{~dB}$, sedangkan pada 4000 dan $8000 \mathrm{~dB}$ kenaikan $>50 \mathrm{~dB} .^{(13)}$

Bervariasinya

pendengaran yang timbul dan kerusakan koklea yang terjadi bersifat individual dan tidak sama pada semua penderita atau binatang percobaan. Diperkirakan hal ini terjadi 
berhubungan dengan mutasi dan polimorfisme gen. ${ }^{(15)}$

Pada penelitian ini, gangguan pende-ngaran yang lebih berat terjadi pada frekuensi tinggi, meskipun pada analisis statistik tidak terdapat perbedaan yang bermakna antara

frekuensi tinggi dan rendah $(\mathrm{p}>0,05)$. Hal ini dapat terjadi karena jumlah sampel yang terbatas dan waktu penilaian yang dini. Laporan-laporan tentang efek cisplatin terhadap pendengaran mendapatkan gangguan pendengaran yang terjadi sensorineural nada/frekuensi tinggi, sesuai dengan temuan patologis yang terjadi bahwa kerusakan terutama pada bagian basal koklea. ${ }^{(8,9,13)}$

Hasil penelitian ini berbeda dengan laporan Berg $\mathrm{AL} \mathrm{dkk,}{ }^{(8)}$ yang mendapatkan peningkatan nilai ambang hanya pada nada tinggi $(\geq 3000 \mathrm{~Hz})$, tidak satupun pada frekuensi $500 \mathrm{~Hz}$. Hal yang mirip juga dilaporkan Laurell $\mathrm{G} \mathrm{dkk},{ }^{(13)}$ yang juga tidak menemukan perubahan ambang dengar pada frekuensi 500 sampai $2000 \mathrm{~Hz}$. Pada penelitian ini, peningkatan nilai ambang dengar tidak hanya pada frekuensi tinggi tetapi juga terdapat pada frekuensi rendah, meskipun perubahannya lebih kecil dari pada pada frekuensi tinggi.

\section{KESIMPULAN}

Dari penelitian ini dapat disimpulkan bahwa setelah pemberian satu siklus kemoterapi cisplatin 100 $\mathrm{mg} / \mathrm{m}^{2}$ sebagian besar sampel tidak mengalami perubahan ambang dengar pada frekuensi 250, 500, 1000, 2000, 4000 dan $6000 \mathrm{~Hz}$, sedangkan pada frekuensi $8000 \mathrm{~Hz}$, sebagian besar mengalami kenaikan nilai ambang dengar. Namun demikian nilai rerata hantaran tulang sebelum dengan setelah kemoterapi terdapat perbedaan yang bermakna pada semua frekuensi. Proporsi gangguan pendengaran $\geq 10$ $\mathrm{dB}$ lebih besar pada frekuensi tinggi dari pada frekuensi rendah, namun perbedaan ini tidak bermakna secara statistik.

\section{KEPUSTAKAAN}

1. Jongh FE, Veen RN, Veltman SJ, dkk. Weekly High-dose cisplatin is a feasible treatment option: analysis on prognostic factors for toxicity in 400 patients. $\mathrm{Br} \quad \mathrm{J}$ Cancer 2003;88:1199-206.

2. Ekborn A, Lindberg A, Laurell G, Wallin I, Ekborg S, Ehrsson H. Ototoxicity, nephrotoxicity and pharmacokinetics of cisplatin and its monohidrated complex in guinea pig. Cancer Chemother

Pharmacol 2003;51:36-42.

3. Zorat PL, Paccagnella A, Cavaniglia G, Loreggian L, Gava A. Randomized Phase III Trial of Neoadjuvant Chemotherapy in Head and Neck Cancer: 10-years followup. J Natl Cancer Inst 2004;96:1714-7.

4. Skeel RT. Antineoplastic Drugs and Biologic response modifiers: Classification, use, and toxicity of Clinically useful agents. Dalam: Skeel RT. Handbook of Cancer Chemotherapy, $\quad 7^{\text {th }}$ ed. Lippincott Williams \& Wilkins; 2007.p.53-168.

5. Dutta A, Venkatesh MD, Kashyap RC. Study of the effects of chemotherapy on 
auditory function. Indian $\mathbf{J}$ Otolaryngol. 2005; 57(3): 2268 .

6. Blakley BW, Cohen JI, Doolittle ND, dkk. Strategies for prevention of toxicity caussed by platinum based chemotherapy: Review and summery of annual meeting of the blood-brain barrier disruption program, Gleneden beacch, Oregon, March 10, 2001. Laryngoscope 2002; 112:1997-2000.

7. Vasquez R, Mattucci KF. A proposed protocol for monitoring ototoxicity in patients who take cochleo or vestibulotoxic drugs. ENT Journal 2003;82(3):181-4.

8. Berg AL, Spitzer JB, Garvin JH. Ototoxic impact of cisplatin in pediatric oncology patients. Laryngoscope 1999; 109:180614.

9. Lakhai JMR, Crul M, Zuur L, et al. Relationship between cisplatin administration and the development of ototoxicity. J Clin Oncol 2006; 24(6): 91824.

10. Biro K, Noszek L, Prekopp P, Nagyivanyi K, Geczi L, Gaudi I. Characteristics and risk factors of cisplatin-induced ototoxicity in testicular cancer patients detected by distorsion product otoacoustic emmision. Oncology 2006; 70: 177-84.

11. Durrant JD, Rodgers G, Myers EN, Johnson JT. Hearing lossrisk factor for cisplatin ototoxicity? Observations. Am J Otol 1990;11(5):375-7.

12. Schaefer SD, Post Jimmy D, Close LG, Wright CG. Ototoxicity of low and moderate dose cisplatin. Cancer 1985; 56:1934-9.

13. Laurell G, Jungnelius U. High dose cisplatin treatment: hearing loss and plasma concentrations. Laryngoscope 1990; 100:724-34.

14. Zuur CL, Simis YJ, Lansdaal PE, Hart AA, Rasch CR, Schornagel JH, Dreschler WA, Balm AJ. Risk factors of ototoxicity after cisplatin-based chemo-irradiation in patients with locally advanced headand-neck cancer: A multivariate analysis. Int $\mathrm{J}$ Radiation Oncology, biol, phys 2007; 68(5): 1320-5.

15. Knoll C, Smith RJH, Shores C, Blatt J. Heraing genes and cisplatin deafness: a pilot study. Laryngoscope 2004; 116: 72-4. 